\title{
EFFECT OF SUPPLEMENTATION WITH SOLID-STATE FERMENTED FEED IN THE DIET OF LAYING HENS ON EGG QUALITATIVE VARIABLES
}

\author{
Boris Semjon, Eva Dudriková, Iveta Jad'uttová, Martin Bartkovský, Tatiana Klempová, \\ Dana Marcinčáková, Ondrej Slaný, Slavomír Marcinčák
}

\begin{abstract}
The aim of this experiment was to evaluate the effect of the supplementation of laying hens diet with solid-state fermented feed on egg qualitative variables. The diet of laying hens was supplemented with $10 \%$ and $15 \%$ of solid-state feed fermented by the low filamentous fungal strain Mortierella alpina CCF 2861. For the trial, 30 Lohmann Brown classic layers, aged 17 weeks, were selected and individually weighed and divided into three groups (control and two experimental groups). The control group of laying hens was fed with basic feed mixture and the experimental groups received the same diet as a control group, but enriched with supplementation of solid-state fermented feed. The first experimental group was fed a diet supplemented with $10 \%$ of fermented feed and the second experimental group with $15 \%$ supplementation. The following egg qualitative variables were observed: the egg weight, Haugh units, quality grade, air cell depth, percentage of the shell, yolk and albumen, eggshell breaking force, $\mathrm{pH}$ of egg yolk and albumen, egg yolk colour, and antioxidant activity with the extent of lipid oxidation in egg yolk samples. The $\mathrm{pH}$ of yolk and albumen did not show differences between all examined eggs originating from the experimental groups of laying hens $(p>0.05)$. The eggs from both experimental groups had a significantly higher eggshell hardness than eggs produced by the hens of the control group $(p<0.05)$. Antioxidant activity of egg yolk of experimental samples increased with the supplementation of fermented feed in the diet of laying hens $(p<0.05)$. The specific lightness of egg yolk colour increased significantly in the experimental group with $15 \%$ of supplementation $(p<0.01)$. The obtained results showed that feeding laying hens with fermented feed positively affected the quality of produced eggs. This was the first study and further investigation before using the fermented feed in commercial laying hen farms is necessary.
\end{abstract}

Keywords: laying hen; egg; quality; solid-state fermented feed; colourimetry

\section{INTRODUCTION}

Eggs are an important source of polyunsaturated fatty acids (PUFA) in human nutrition. PUFA are biologically active substances that are beneficial for human health. The positive effect of PUFA on health is very well known. They are components of cell membranes and precursors of eicosanoids (Gladkowski et al., 2011). They regulate architecture, dynamics, phase transition, and permeability of membranes as well as the behaviour of some membrane-bound proteins. In addition, PUFA, as essential compounds, are precursors of a multitude of diverse metabolites, such as prostaglandins, leukotrienes, and hydroxy fatty acids (Ghadiri et al., 2016; Wang et al., 2017). Eggs are also interesting from the viewpoint that the content of individual significant n-3 and n-6 PUFAs in the lipid portions of an egg can be very easily changed by the composition of the fatty acids in the feed of laying hens. The weight and composition of a table egg are dependent on heredity, age, season, diet, and other factors (Kusum et al. 2018). The main chemical components of hen egg are $12 \%$ lipids, $12 \%$ proteins, and the rest is water and small amounts of carbohydrates and minerals (Sugino,
Nitoda and Juneja, 1997). Most of the proteins are present in the egg white and the egg yolk, amounting to $50 \%$ and $44 \%$, respectively; the eggshell contains the rest of the proteins (Kusum et al. 2018). The protein fraction is distributed in both egg white (ovalbumin, ovotransferrin, ovomucoid, ovomucin, etc.) and yolk (high-density lipoproteins, low-density lipoproteins and livetins) (Nimalaratne and $\mathbf{W u}, 2015)$. The yolk accounts for slightly over one-third of the edible portion, but it yields three-fourths of the calories and provides all or most of the fat in whole eggs The yolk comprises $48 \%$ water, $16 \%$ protein, $32.6 \%$ fat, and some minerals and vitamins. The white consists of $88 \%$ water, $10 \%$ protein, and some minerals (Ren, Wu and Renema, 2010). The yolk is a complex milieu containing $68 \%$ low-density lipoproteins (LDL), $16 \%$ high-density lipoproteins (HDLs), $10 \%$ livetins and other soluble proteins, and 4\% phosvitins (Réhault-Godbert, Guyot and Nys, 2019). The amount of lipid in the egg white is negligible $(0.01 \%)$ compared with the amount present in the yolk. The shell makes up $11 \%$ of the weight of an egg, and approximately $98 \%$ of the shell consists of calcium. Carbohydrates are a minor 
component of hen eggs. Their average content is about 0.5 g per egg, $40 \%$ of which is present in the yolk. (Ren, Wu and Renema, 2010; Kusum et al. 2018).

Many egg proteins such as ovalbumin, ovotransferrin, phosvitin, egg lipids such as phospholipids, as well as certain micronutrients such as vitamin E, vitamin A, selenium, and carotenoids, are reported to have antioxidant properties, which prevents or removes oxidative damage to a target molecule by the regulation of antioxidant defence or inhibition of radicals production (Nimalaratne and Wu, 2015).

Numerous studies have been published on the supplementation of hen's diets with ALA-rich seeds or oil; EPA/DHA-rich fish oil, fish oils combined with humic preparations (Gladkowski et al., 2011), microalgae (such as biomass of Spirulina maxima) (Saeid and Chojnacka, 2015; Neijat, et al., 2016; Saeid et al., 2016).

Industrial processing of feeds destined for animal consumption and human nutrition results in high amounts of agroindustrial residues. Most of these residues have nutritional potential (Graminha et al., 2008). These residues have been classified as agro-industrial byproducts and recently they have been receiving greater attention (Eun et al., 2006). In terms of cost efficiencies, the replacement of expensive conventional feedstuffs in animal diets with cheaper unconventional fermented feedstuffs may further encourage the use of the latter (Sugiharto and Ranjitkar, 2019).

Solid-state fermentation (SSF) is the oldest known fermentation technique, which imitates the natural environment of the microorganism (Marcinčák et al., 2018). SSF is characterized as a process in which microorganisms grow on a moist solid substrate in the absence of free water, simulating the fermentation reactions occurring in nature (Pandey, 2003). Low filamentous fungi strains used in the SSF process simultaneously decrease the anti-nutrient compounds in the substrates and partially hydrolyse substrate biopolymers, the pre-fermented mass with a high content of PUFA, which may be used as an inexpensive food and feed supplement (Čertík et al., 2008).

Several strains of oleaginous lower fibrous fungi, in particular Mortierella, Cunninghamella, Mucor, Thamnidium, Pythium and Thraustochytrium, are a good source of PUFAs (Čertík et al., 2013). Mortierella alpina is a food-grade oleaginous fungus with the ability to release a high level of PUFAs, especially arachidonic acid (C 20:4-n-6) and eicosapentaenoic acid (C 20:5-n-3) (Dai et al., 2016). The solid-state fermented feed, prepared by fermentation of distiller's dried grains with solubles and soybean meal by Mortierella alpina respectively, was successfully applied in poultry nutrition, resulting in an enhanced amount of PUFA in chicken breast meat (Yang and Zhang, 2016). The product from the SSF process increased the PUFA content in chicken breasts and enhanced the proportions of $n-6$ and $n-3$. Hence, the requirement for new natural nutritional products could be potentially fulfilled by the method of the fermentation process (Klempová et al. 2013) and the subsequent use of the fermented products in the diet of laying hens. Pertaining to our studies, it should improve the egg quality and nutritional value of produced eggs, e.g. by the increase of PUFA content in egg yolk.
One of the most important factors is feeding of the laying hens, not only because of the effect on egg yolk colour but also because of the quality and safety of the final product. Many external and internal factors (Tůmová and Ebeid, 2005; Dvořák et al., 2007) affect the quality of eggs used in human nutrition. A multitude of scientific literature and data exist that discuss the replacement of corn, which represents the main ingredient of poultry diets, accounting for $60-70 \%$ of feed costs (Laganá et al., 2011). For this purpose, soybean meal, sorghum, broken rice, millet, cassava meat, etc. have been proposed. However, a carotenoid source, or annatto (Bixa Orellana L.), and curcumin (main pigment in turmeric roots - Turmeric longa L.), must be added to ensure egg yolk pigmentation (Assuena et al., 2008. On the other hand, the dietary carrot can influence both the physical characteristics of the egg and yolk colour, the latter of which contains a higher amount of carotenes and a lower amount of xanthophylls and paprika (Spasewski et al., 2018). It is known that egg yolk colour is affected mostly by the diet of the hen (Colin et al., 2004), and the main source of pigment in conventional diets is yellow corn (Lokaewmanee et al., 2010).

The main challenge of our research was evaluating the effect of supplementation of the diet of laying hens with solid-state fermented feed on egg qualitative variables. The diet of laying hens was supplemented with $10 \%$ and $15 \%$ of solid-state fermented feed by the filamentous fungi Mortierella alpina CCF 2861.

\section{Scientific hypothesis}

1. We assume that supplementation of solid-state fermented feed in the diet of laying hens affects the physical variables of the egg.

2. We assume that egg yolk colour of eggs will be affected by the application of solid-state fermented feed in the diet of laying hens belonging to the experimental groups.

3. We assume that solid-state fermented feed in the diet of laying hens influences antioxidant activity and extent of the lipid oxidation in egg yolk samples.

4. We assume that a higher impact will be made on qualitative variables of produced eggs with supplementation of $15 \%$ of solid-state fermented feed in the diet of laying hens, in comparison to $10 \%$ supplementation.

\section{MATERIAL AND METHODOLOGY}

The animal protocol for this research was approved by the Ethical Committee for Animal Care and Use of University of Veterinary Medicine and Pharmacy in Kosice (The Slovak Republic). The experiment was carried out in accordance with the 'European Directive on the Protection of Vertebrate Animals Used for Experimental and Other Scientific Purposes' (European Parliament and Council, 2010).

\section{Preparation of fermented feed}

Fermented feed (FF) was prepared by fungal solid-state fermentation (SSF) according to the modified method of Čertík et al. (2006). The low filamentous fungal strain Mortierella alpina CCF 2861 was used. M. alpina CCF 
2861 was obtained from the Culture Collection of Fungi, Charles University, Prague, Czech Republic. For the preparation of the spore suspension, which was inoculated with the SSF substrate, M. alpina CCF 2861 was grown for 10 days on rice. After 10 days, the spores were washed with distilled water with $0.05 \%$ Tween 80 and filtered through a gauze to remove the solid substrate. The spore suspension thus prepared was diluted to a concentration of $2.10^{5}$ spores. $\mathrm{mL}^{-1}$. Wheat bran was used as a substrate.

\section{Birds, Housing, Diets and Experimental Design}

The experiment was carried out at the University of Veterinary Medicine and Pharmacy in Košice.

For the trial, 30 laying hens Lohmann Brown classic layers aged 17 weeks, were individually weighed and divided into three groups (10 hens per pen).

The control group of laying hens (C) was fed with a commercial feed mixture without the supplementation of FF (De Heus, Bučovice, Czech Republic). Components of commercial feed mixture were corn, wheat, calcium carbonate, sunflower pomace, soya meal, rapeseed meal, wheat bran, corn gluten feed, barley, dark distillery grape, vinasse, vegetable oil and sunflower fat, monocalciumphosphate and sodium chloride. The nutrition composition of basal and experimental feed mixtures is presented in Table 1.

The first experimental group of laying hens (FF10) was fed with commercial feed mixture supplemented with $10 \%$ of FF, and second experimental group with $15 \%$ supplementation (FF15). First two weeks of acclimatization for animals were assigned to the experimental groups. Fermented feed was supplemented to the laying hens after the beginning of egg performance, in the $21^{\text {st }}$ week.

\section{Determination of egg qualitative variables}

To determine egg quality, 150 eggs, collected from week 25 , were used for analyses.

Egg AnalyzerTM (Orka Food Technology Ltd., Ramat HaSharon, Israel) was used to determine the egg weight,
Haugh units (HU), quality grade and yolk colour. The device has measured egg weight $(\mathrm{g})$, the height of the thick albumen ( $\mathrm{mm})$, and colour of the yolk. The first two measurements were used for calculation of $\mathrm{HU}$, which indicates egg quality. The equation for working out the rating is shown below: $\mathrm{HU}=100 \log \left(\mathrm{h}-1.7 \mathrm{w}^{0.37}+7.6\right)$, where: $\mathrm{HU}=$ egg quality in Haugh units; $w=$ egg weight in grams; $h=$ height of the thick albumen in mm (Nagy et al., 2011).

The air cell depth of eggs was expressed in millimetres. The percentage of shell, yolk and albumen was calculated.

Eggshell breaking force was measured in accordance with the manufacturer's instructions by the Egg force reader (Orka Food Technology Ltd., Ramat HaSharon, Israel) - a compact system for automatic measuring of the eggshell breaking point. The unit of strength measurement involves gentle application of force on the eggshell until it cracks. The results were interpreted as kilogram-force (kgf).

The $\mathrm{pH}$ of egg yolk and albumin were measured by the WTW $7110 \mathrm{pH}$ meter (WTW GmbH, Weilheim, Germany). Antioxidant activity of yolk was detected spectrophotometrically by the method of 2,2-diphenyl-1picrylhydrazyl (DPPH) scavenging (Brand-Williams et al., 1995). The extent of lipid oxidation in egg yolk samples was evaluated via measurement of thiobarbituric acid reactive substances (TBARS) according to the method Reitznerová et al. (2017). Thiobarbituric acid reactive substances (TBARS) values were measured spectrophotometrically at $532 \mathrm{~nm}$ (Helios c; Thermo spectronic, Cambridge, UK). The results were quantified as MDA equivalents (mg. $\mathrm{kg}^{-1}$ ).

Colour of egg yolk was determined by Minolta Chroma Meter CR-410 (Ø $50 \mathrm{~mm}$, average daily light with a colour temperature of about $6500 \mathrm{~K}$ (D65) (Konica Minolta, Sensing, Inc. Japan), using a programme of a Colour Data Software CM-S100w SpectraMagic ${ }^{\mathrm{TM}}$ NX (Konica Minolta Sensing Inc., Osaka, Japan, 2014). The equipment was calibrated against a standard light white reference tile and the measurements were conducted under a $2^{\circ}$ standard observer angle. The colour parameters $L^{*}-$ lightness was

Table 1 The nutritional composition of laying hens diet

\begin{tabular}{|c|c|c|c|c|}
\hline & FF & $\mathbf{C}$ & FF10 & FF15 \\
\hline Dry matter $\left[{\left.\mathrm{g} . \mathrm{kg}^{-1}\right]}^{-1}\right.$ & 1000.00 & 1000.00 & 1000.00 & 1000.00 \\
\hline Crude protein $\left[{\left.\mathrm{g} . \mathrm{kg}^{-1}\right]}^{-1}\right.$ & 193.38 & 157.53 & 167.12 & 165.64 \\
\hline Crude fat $\left[\mathrm{g} \cdot \mathrm{kg}^{-1}\right]$ & 50.14 & 37.23 & 41.70 & 38.72 \\
\hline Crude fiber $\left[{\left.\mathrm{g} . \mathrm{kg}^{-1}\right]}^{-1}\right.$ & 169.07 & 58.88 & 76.15 & 78.42 \\
\hline Ash $\left[\mathrm{g} . \mathrm{kg}^{-1}\right]$ & 75.75 & 154.33 & 147.37 & 112.19 \\
\hline Starch $\left[\right.$ g.kg $\left.{ }^{-1}\right]$ & 75.53 & 411.84 & 353.01 & 371.76 \\
\hline $\mathrm{Ca}\left[\mathrm{g} . \mathrm{kg}^{-1}\right]$ & 1.63 & 20.00 & 19.75 & 15.40 \\
\hline$P\left[g^{.} \mathbf{k g}^{-1}\right]$ & 5.97 & 4.86 & 5.93 & 4.40 \\
\hline $\operatorname{Mg}\left[\mathrm{g} . \mathrm{kg}^{-1}\right]$ & 4.34 & 3.09 & 3.29 & 3.41 \\
\hline $\mathrm{Ma}\left[\mathrm{g} . \mathrm{kg}^{-1}\right]$ & 0.22 & 2.21 & 2.41 & 0.99 \\
\hline$K\left[g^{\prime} \cdot \mathrm{kg}^{-1}\right]$ & 13.02 & 7.51 & 8.12 & 7.92 \\
\hline $\mathrm{Cu}\left[\mathrm{mg} . \mathrm{kg}^{-1}\right]$ & 36.03 & 44.19 & 73.52 & 41.79 \\
\hline $\mathrm{Zn}\left[\mathrm{mg} . \mathrm{kg}^{-1}\right]$ & 106.78 & 101.63 & 96.57 & 64.89 \\
\hline Mn [mg.kg $\left.{ }^{-1}\right]$ & 195.44 & 173.44 & 176.67 & 166.08 \\
\hline
\end{tabular}

Note: FF - fermented feed; C - control group of laying hens; FF10 - laying hens fed with diet supplemented with $10 \%$ of fermented feed; FF15 - laying hens fed with diet supplemented with $15 \%$ of fermented feed; $S D$ - standard deviation. 
measured on a scale of 0 to $100 \%$; $\mathrm{a}^{*}$ - redness; $\mathrm{b}^{*}-$ yellowness. Colour measurements were determined according to the CIELab colour space system (Commission Internationale de l'Eclairage, 1986).

The instrument was calibrated with a white reference plate (Konica Minolta, Sensing, Inc. Japan), with setting values $\left(\mathrm{L}^{*}=97.10, \mathrm{a}^{*}=-4.88, \mathrm{~b}^{*}=7.04\right)$ before the measurement.

CIE total colour difference $\left(\Delta \mathrm{E}^{*}\right)$, as the distance between the two points, was calculated according to the following formula: $\Delta \mathrm{E}^{*}=\left[\left(\Delta \mathrm{L}^{*}\right)^{2}+\left(\Delta \mathrm{a}^{*}\right)^{2}+(\Delta \mathrm{b})^{2}\right]^{1 / 2}$. Chroma $C^{*}$ represents a value which measures the extent to which the particular colourity differs from grey. Chroma $\mathrm{C}^{*}$ was calculated according to this formula: $\mathrm{C}^{*}=\left(\mathrm{a}^{* 2}+\right.$ $\left.\mathrm{b}^{* 2}\right)^{1 / 2}$. Hue $\mathrm{h}_{\mathrm{ab}}$ is expressed as the name of colour and this value was calculated according to the following formula: $\mathrm{h}_{\mathrm{ab}}=\operatorname{tg}^{-1}(\mathrm{~b} * / \mathrm{a} *)$.

\section{Statistical analysis}

Data analysis was carried out with GraphPad Prism 8.3.0.538 (GraphPad Software, San Diego, California, USA). The effect of the supplementation of laying hens diet with solid-state fermented feed with $10 \%$ and $15 \%$ on egg qualitative variables was set as the main factor. A oneway analysis of variance (ANOVA), followed by Tukey's post-test, was conducted and a confidence interval was set at $95 \%$.

\section{RESULTS AND DISCUSSION}

Table 2 shows the results of the physical variables of eggs produced in the $25^{\text {th }}$ week. The maximum egg weight was detected in the experimental group of laying hens $(53.13 \pm 3.74 \mathrm{~g})$ after $10 \%$ addition of fermented feed (FF10). Egg yolk weight increased in the experimental group FF15 to the value of $12.24 \pm 1.25 \mathrm{~g}$ per egg. Eggshell mean weight ranged from $6.91 \pm 0.58 \mathrm{~g}$ (FF15 group) to $7.48 \pm 1.92 \mathrm{~g}$ in the eggs originating from the control group (C) of laying hens. However, no statistically significant effect on physical variables of produced eggs was observed when the experimental diet was provided ( $p$ $>0.05)$.

The effect of solid-state fermented feed on quality of the produced eggs was examined on the fifth week of egg performance (in $25^{\text {th }}$ week). The results of the qualitative variables determinations are shown in Table 3. The eggs from F10 and FF15 experimental group had a significantly higher eggshell hardness, $5.80 \pm 0.96 \quad \mathrm{kgf}$ and $5.69 \pm 0.65 \mathrm{kgf}$, respectively, than eggs produced by the $\mathrm{C}$ laying hens group $(2.78 \pm 1.16 \mathrm{kgf})$, which were fed only with basic feed mixture $(p<0.05)$. The supplementation of $15 \%$ fermented feed in diet of the FF15 group showed an increase in HU values of egg performance. The experimental supplementation in the diet of laying hens had no significant effects on egg quality traits (Table 3 ) in terms of yolk and albumen index and in the size of air bubbles

$(p>0.05)$. The $\mathrm{pH}$ of yolk and albumen did not show significant differences between both experimental groups of laying hens $(p>0.05)$.

The eggshell hardness was statistically different among the experimental groups $(p<0.05)$. Maximum eggshell hardness was determined in egg samples of FF10 group, which was 2.86 times higher than in the eggs of $\mathrm{C}$ group (Table 3). The supplementation of laying hens with an experimental diet showed a significant effect on eggshell hardness $(p<0.05)$.

The results of DPPH radical scavenging activity (antioxidant activity) and malondialdehyde content in egg yolk samples of produced eggs are presented in Table 4. The antioxidant activity of the egg yolk was affected by the feeding of both $10 \%$ and $15 \%$ supplementation with fermented feed. The ability to scavenge free DPPH radicals was significantly higher in egg yolk of experimental groups (FF10 and FF15) in comparison to the values obtained for the eggs from the control group ( $p$ $<0.05)$.

Malondialdehyde (MDA) values in samples of the eggs were lower for groups FF10 and FF15 than in the control group $(\mathrm{C})$, although the differences between values for this parameter did not show significant differences $(p>0.05)$.

Colourimetric parameters of egg yolks, obtained from eggs belonging to the experimental groups, were measured by Minolta Chroma Meter CR-410 (Ø $50 \mathrm{~mm}$, average daily light with colour temperature of about $6500 \mathrm{~K}$ (D65), standard measurement angle $2^{\circ}$ ) and are listed in Table 5 .

$\mathrm{L}^{*}$ variable, which represents light shade intensity $(0$ - black, 100 - white), exhibited a significant difference $(p<0.01)$. A decrease in the mean value of $\mathrm{L}^{*}$ variable in the FF15 indicates darkening of the egg yolk. This suggests that the egg yolk from the eggs of laying hens fed with supplementation of $15 \%$ fermented feed contains higher concentrations of colour pigment. Variable $a^{*}$ reflects the changes in the area of red-colour wavelengths and can reach a maximum in sharp red colour $(+120)$ or a minimum in green-blue colour (-80). Egg yolk obtained from all experimental groups of laying hens showed no significant changes in indicator $\mathrm{a}^{*}(p>0.05)$.

According to the colour measurements, descriptive egg parameters were numerically affected only by the mean of $\mathrm{L}^{*}$ variable and statistically differed $(p<0.01)$. The highest $L^{*}$ value was obtained with higher egg yolk colour in FF15 of experimental eggs. The presented egg yolk colour was not significantly different in $a^{*}, b^{*}, h^{*}, C^{*}$ and index of egg yolk values, respectively.

Table 2 Physical variables of produced eggs in the $25^{\text {th }}$ week of egg performance (mean $\left.\pm S D\right)$.

\begin{tabular}{lccc}
\hline & C & FF10 & FF15 \\
\hline Egg weight [g] & $52.31 \pm 2.71$ & $53.14 \pm 3.74$ & $51.90 \pm 2.57$ \\
Yolk [g] & $12.50 \pm 0.14$ & $12.15 \pm 0.94$ & $12.24 \pm 1.25$ \\
Albumin [g] & $32.33 \pm 1.86$ & $33.62 \pm 3.77$ & $32.75 \pm 1.04$ \\
Eggshell [g] & $7.48 \pm 1.92$ & $7.37 \pm 0.91$ & $6.91 \pm 0.58$ \\
\hline
\end{tabular}

Note: C - control group of laying hens; FF10 - laying hens fed with diet supplemented with $10 \%$ of fermented feed; FF15

- laying hens fed with diet supplemented with $15 \%$ of fermented feed; $S D$ - standard deviation. 
The specific lightness of egg colour, e.g. indicator L*, increased significantly in FF15 experimental group $(p<0.01)$. Variable $a^{*}$ (red colour) in experimental eggs remained unaffected, egg yolk showed a trend towards orange colour (Table 5). Value of variable $b^{*}$ slightly increased after supplementation with $10 \%$ of fermented feed in hens diet and slightly decreased with $15 \%$. However, the corresponding differences were not significant $(p>0.05)$.

The indicators of colourity are shown in Table 5. Hue $\mathrm{h}^{*}$ slightly increased (FF10) and decreased (FF15) with fermented feed. However, the change in $\mathrm{h}^{*}$ variable was not significant $(p>0.05)$. Also, chroma $\mathrm{C}^{*}$ variable (the value by which particular colourity differs from grey) does not represent significant differences among groups $(p>0.05)$.

Table egg colour can be controlled by a subjective method, with DSM YolkFan ${ }^{\mathrm{TM}}$ or an objective method, the chromameter Minolta (Hamelin and Hernandez, 2011). CIE total colour difference $\left(\Delta \mathrm{E}^{*}\right)$ was the only indicator that differs from the control. The difference was higher for the higher dose (2.61) of fermented feed in the diet of laying hens than for the lower dose (1.96) of fermented feed, $15 \%$ and $10 \%$, respectively. The absolute value of the difference between FF10 and FF15 groups of experimental laying hens was low, 0.65. A $\Delta \mathrm{E}^{*}$ value higher than 1.00 expresses that the colour difference of two samples, which are measured, is detectable with human eye.

Egg producers, consumers and processors' perspectives have different meanings for the definition of egg quality. Easy eggshell removal and separation of the yolk from the albumen, as well as functional properties of eggs, are very important for the processors of eggs (Alleoni and Antunes, 2001). For the egg producers, egg quality usually means the egg weight and quality of eggshell, whereas consumers are interested mostly in shelf life, the external appearance of eggs and sensorial qualities, such as eggshell and yolk colour (Faitarone et al., 2016; Ketta and Tůmová, 2016).

Several studies have been published in recent years, in which filamentous fungi in SSF feed were successfully applied in poultry nutrition. However, most published scientific articles with an application of SSF feed in poultry production are related to broilers nutrition (Bača et al., 2014; Marcinčák et al., 2018; Sugiharto and Ranjitkar, 2019). On the other hand, supplementation of laying hens diet with microbial probiotics, plant additives,

Table 3 The results of qualitative variables of produced eggs (mean $\pm S D$ ).

\begin{tabular}{lccc}
\hline \multicolumn{1}{c}{ Variable } & C & FF10 & FF15 \\
\hline Eggshell hardness [kgf] & $2.78 \pm 1.16^{\mathrm{a}}$ & $5.80 \pm 0.96^{\mathrm{b}}$ & $5.69 \pm 0.65^{\mathrm{b}}$ \\
Haugh unit & $65.66 \pm 23.19$ & $64.42 \pm 31.34$ & $71.52 \pm 13.90$ \\
Air cell [mm] & $1.56 \pm 0.60$ & $1.74 \pm 0.25$ & $1.74 \pm 0.25$ \\
Yolk index [\%] & $40.71 \pm 6.59$ & $39.78 \pm 6.38$ & $37.32 \pm 3.52$ \\
Albumen index [\%] & $6.84 \pm 4.05$ & $7.96 \pm 2.29$ & $7.08 \pm 3.22$ \\
Yolk pH & $6.03 \pm 0.02$ & $6.12 \pm 0.03$ & $6.06 \pm 0.01$ \\
Albumen pH & $8.26 \pm 0.03$ & $8.39 \pm 0.02$ & $8.38 \pm 0.02$ \\
\hline
\end{tabular}

Note: C - control group of laying hens; FF10 - laying hens fed with diet supplemented with $10 \%$ of fermented feed; FF15 - laying hens fed with diet supplemented with $15 \%$ of fermented feed; $S D$ - standard deviation. ${ }^{\mathrm{a}-\mathrm{b}}-$ in a row means without a common superscript letter differ $(p<0.05)$.

Table 4 The results of DPPH radical scavenging activity (antioxidant activity) and malondialdehyde content in egg yolk samples (mean $\pm S D)$.

\begin{tabular}{lccc}
\hline \multicolumn{1}{c}{ Variable } & C & FF10 & FF15 \\
\hline Antioxidant activity [\%] & $21.68 \pm 1.26^{\mathrm{b}}$ & $24.12 \pm 0.30^{\mathrm{a}}$ & $25.18 \pm 0.46^{\mathrm{a}}$ \\
MDA [mg.kg ${ }^{-1}$ ] & $0.95 \pm 0.13$ & $0.89 \pm 0.33$ & $0.94 \pm 0.13$ \\
\hline
\end{tabular}

Note: C - control group of laying hens; FF10 - laying hens fed with diet supplemented with $10 \%$ of fermented feed; FF15 - laying hens fed with diet supplemented with $15 \%$ of fermented feed; MDA - malondialdehyde; $S D$ - standard deviation. $^{\mathrm{a}-\mathrm{b}}$ - in a row means without a common superscript letter differ $(p<0.05)$.

Table 5 The results of colourimetric variables of egg yolk samples (mean $\pm S D$ ).

\begin{tabular}{|c|c|c|c|}
\hline Variable & $\bar{C}$ & FF10 & FF15 \\
\hline $\mathbf{L}^{*}$ & $95.82 \pm 2.06^{\mathrm{a}}$ & $96.90 \pm 3.36^{\mathrm{a}}$ & $93.50 \pm 1.62^{b}$ \\
\hline $\mathbf{a}^{*}$ & $33.20 \pm 6.77^{\mathrm{a}}$ & $32.03 \pm 5.47^{\mathrm{a}}$ & $34.340 \pm 3.37^{\mathrm{a}}$ \\
\hline $\mathbf{b}^{*}$ & $115.55 \pm 6.11^{\mathrm{a}}$ & $116.69 \pm 8.61^{\mathrm{a}}$ & $115.89 \pm 2.69^{\mathrm{a}}$ \\
\hline C* & $120.35 \pm 7.33^{\mathrm{a}}$ & $121.22 \pm 7.13^{\mathrm{a}}$ & $120.92 \pm 2.82^{\mathrm{a}}$ \\
\hline h* & $74.09 \pm 2.64^{\mathrm{a}}$ & $74.47 \pm 3.47^{\mathrm{a}}$ & $73.50 \pm 1.54^{\mathrm{a}}$ \\
\hline YI & $142.72 \pm 7.57^{\mathrm{a}}$ & $141.47 \pm 3.83^{\mathrm{a}}$ & $145.21 \pm 3.94^{\mathrm{a}}$ \\
\hline
\end{tabular}

Note: C - control group of laying hens; FF10 - laying hens fed with diet supplemented with $10 \%$ of fermented feed; FF15 - laying hens fed with diet supplemented with $15 \%$ of fermented feed; L* - lightness; a* - red/greenness; b* - blue/yellowness; $C^{*}$ - chromaticity; YI - index of yellow colour according to the standard DIN $6167 ; S D-$ standard deviation. ${ }^{\mathrm{a}-\mathrm{b}}$ - in a row means without a common superscript letter differ $(p<0.05)$. 
etc. were also studied. The influence of probiotic preparation based on lactobacillus, oregano essential oil, sumac (Rhus coriaria), propolis and pollen on egg quality parameters of Lohmann hybrid laying hens were studied by the authors Arpášová et al. (2012), who observed that supplementation did not negatively affect monitored egg quality parameters. Influence of dietary inclusion of Bacillus licheniformis on laying performance, egg quality, antioxidant enzyme activities, and intestinal barrier function of laying hens was also studied (Lei et al., 2013). The quality of the table eggs, their damage and spoiling in various age of the laying hens during the second phase of the laying cycle was studied by the authors Angelovičová, Ševčíková and Angelovič (2015), who assumed that the values of egg shell weight were not directly related to egg weight and egg white weight.

Nevertheless, egg quality remains an interesting subject to investigate. Organoleptic properties and consumption of eggs are associated with the egg quality variables. Kozelová et al. (2018) examined the opinions of the Slovak consumers about the purchase and consumption of eggs and identified their preferences at egg purchase.

A wide variety of scientific literature investigates how the quality and composition of eggs can be altered concerning their use for human nutrition. These changes are often caused by the diet, using some specific ingredients in the feed of laying hens to reach a change in the profile of yolk lipids, mostly to improve the content of lipid fatty acid composition (Koreleski et al., 2003; Faitarone et al., 2016). On the other hand, if the diet of laying hens contains sources of PUFA, e.g. via vegetable oil supplementation, the yolk of eggs can present high lipid oxidation, when compared with those derived from laying hens fed a diet without supplementation. Faitarone et al. (2016) stated in their work that the analysis of variance showed significant differences in yolk lipid oxidation values in eggs laid by white layers fed diets supplemented with different vegetable oils and their concentrations (e.g. linseed, canola, soybean oils and their different mixtures). In this experiment, it was detected, that after 10 days of storage at room temperature, the eggs laid by hens fed a diet with no oil supplementation or supplemented with $2.5 \%$ soybean oil showed a lower degree of yolk lipid oxidation in comparison to the eggs laid by hens fed diets supplemented with 5\% linseed oil and with $2.5 \%$ canola oil $+2.5 \%$ soybean oil. These results were not significantly different from the other treatments. Giampietro et al. (2008) stated that yolk lipid oxidation increased according to egg age, for instance: 0.1343 TBA values in fresh eggs versus 0.1698 in eggs stored for seven days, and 0.2138 in eggs stored for 14 days, respectively. According to Koreleski et al. (2003), TBARS values in eggs stored for 15 days at a temperature from 4 to $8{ }^{\circ} \mathrm{C}$ were significantly higher for control group I (basal diet) and II than in the other groups. The basal diet in those groups was supplemented with $0.3 \%$ Lyso fish fat (groups II, III, IV and V), while reducing the proportion of blended fat by the same amount. So, the lowest yolk fat oxidation was detected in eggs of hens fed the diet supplemented with synthetic antioxidant or vitamin $\mathrm{E}$, and then this was followed by the group supplemented with vitamin C.

Yolk colour was determined as the mean of five readings in the centre of the yolk of each egg by colourimeter
Minolta CR-400. The colour of egg yolk is often related to the egg quality and it is an important biophysical parameter. Yolk colour depends on the chemical and physical properties of the light source (wavelength and intensity) and the actual ability of the observer to perceive colour. Determination of yolk colour in the CIELab system is therefore deemed to be much more beneficial, because information on both colour hue and lightness can be obtained, and such parameters give a good idea of colour changes (Dvořák et al., 2007).

Many scientific works deal with investigating the effect of housing and feeding on the quality of eggs as well as on the yolk colour. Dvořák et al. (2009) refers that, during a 7-month period of monitoring, value $b^{*}$ for egg yolk colour increased significantly from the $3^{\text {rd }}$ month under the deep litter system of rearing. Kopřiva et al. (2014) reported that the addition of dried beetroot at the amount of 1 and $2 \%$ per feeding dose caused a significant increase only in specific lightness (value $\mathrm{L}^{*}$ ). However, lighter egg yolks did not show significant changes in CIELab colour space for values $a^{*}$ and $b^{*}$. This is in agreement with our study.

Therefore, different intensities of yellow are induced by feeding with different feed ingredients. For example, hens fed mash diets containing yellow maize and alfalfa meal laid eggs with dark yellow yolks, while diets based on cereals such as wheat, barley or rice need dietary maize to obtain deep colour (Lokaewmanee et al., 2009). The effect of different levels of marigold and paprika on egg production and yolk colour was also observed by the authors Spasewski et al. (2017). Among yolk sensorial attributes, its colour is considered as a quality indicator, and it, therefore, plays an important role in egg acceptance by the consumers. Higher yolk colour intensity increases egg acceptance by the consumers, who associated more intense yolk pigmentation with higher nutritional value (Silva et al., 2000; Schreiner et al., 2004).

It was concluded that the inclusion of vegetable oils in commercial white layer diets does not significantly change egg yolk pigmentation, as colourimetrically evaluated. The yolks of the eggs laid by layers fed diets containing sources of PUFA presented high lipid oxidation, particularly when compared with those derived from layers fed a diet with no oil supplementation.

Lipid stability is also vital to evaluate, as the yolk fatty acids may suffer lipid oxidation during storage. Lipid stability, as another important egg quality parameter, affects food quality, particularly in aroma, taste and nutritional value, as well as in the production of toxic compounds (Faitarone et al., 2016). Fatty acids, particularly unsaturated fatty acids, are the compounds most susceptible to oxidation (Fennema, 2000). Cherian et al. (2007) reported that the inclusion of PUFA in layer diets may increase the susceptibility of eggs to lipid oxidation.

\section{CONCLUSION}

In this experiment, the effect of supplementing the diet of laying hens with solid-state fermented feed produced by the low filamentous fungal strain Mortierella alpina CCF 2861 on egg qualitative variables was observed. Based on the obtained results, we can conclude that supplementation of laying hens diet with SSF feed (10\% and 15\%) 
positively influenced the quality of eggs in the 25th week of age of laying hens. Further studies are nonetheless necessary to investigate the effect of fermented feed on microbial, physical, and chemical properties of eggs, including the fatty acids profile of eggs. Multiple factorial analysis is a suitable method for further investigation.

\section{REFERENCES}

Alleoni, A. C. C., Antunes, A. J. 2001. Haugh unit as a measure of the quality of hen eggs stored under refrigeration. Sientia Agricola, vol. 58, no. 4, p. 681-685. https://doi.org/10.1590/S0103-90162001000400005

Angelovičová, M., Ševčíková, L., Angelovič, M. 2015. The table eggs and their quality in small-scale breeding. Potravinarstvo Slovak Journal of Food Sciences, vol. 9, no. 1, p. 442-450. https://doi.org/10.5219/515

Arpášová, H., Kačániová, M., Haščík, P., Šidlová, V. 2012. Effect of selected feed additives on internal quality parameters of table eggs. Potravinarstvo Slovak Journal of Food Sciences, vol. 6, no. 4, p. 52-61. https://doi.org/10.5219/235

Assuena, V., Filardi, R. S., Junqueira, O. M., Casartelli, E. M., Laurentiz, A. C., Duarte, K. F. 2008. Replacement of maize by sorghum in laying hens diets formulated to attempt different criteria in amino acids requirements. Ciencia Animal Brasileira, vol. 9, no. 1, p. 93-99.

Bača, M., Marcinčák, S., Čertík, M., Popelka, P., Marcinčáková, D., Guothová, L., Molnár, L., Klempová, T., Maskal'ová, I. 2014. Effect of adding prefermented cereal product containing gamma-linolenic acid to broiler feed on production indicators and fatty acid profile of chicken breast. Acta Veterinaria Brno. vol. 83, no. 4, p. 379-384. https://doi.org/10.2754/avb201483040379

Brand-Williams, W., Cuvelier, M. E., Berset, C. 1995. Use of a free radical method to evaluate antioxidant activity. $L W T$ - Food Science and Technology, vol. 28, no. 1. p. 25-30. https://doi.org/10.1016/S0023-6438(95)80008-5

Colin, G. S., George, B., Ensminger, M. E. 2004. Poultry Science. 4th ed. Upper Saddle River, New Jersey, USA: Pearson Prentice Hall. 512 p. ISBN-13 2900131133753.

Commission Internationale de l'Eclairage (CIE). 1986. Colourimetry. $2^{\text {nd }}$ ed. VIENNA, AUSTRIA: Publication CIE No. 15.2. Commission Internationale de l'Eclairage.

Čertík, M., Adamechová, Z., Hanusová, V., Breirerová, E. 2008. Biotechnology as a useful tool for nutritional improvement of cereal-based materials enriched with polyunsaturated fatty acids and pigments. Acta Agronomica Hungarica, vol. 56, p. 337-384. https://doi.org/10.1556/AAgr.56.2008.4.1

Čertík, M., Klempová, T., Guothová, L., Mihálik, D., Kraic., J. 2013. Biotechnology for the functional improvement of cereal-based materials enriched with polyunsaturated fatty acids and pigments. European Journal of Lipid Science and Technology, vol. 115, p. 1247-1256. https://doi.org/10.1002/ejlt.201300092

Čertík, M., Sláviková, L., Masrnová, S., Šajbidor, J. 2006. Enhancement of Nutritional Value of Cereals with $\gamma$ Linolenic Acid by Fungal Solid-State Fermentations. Food Technology \& Biotechnology, vol. 44, no. 1, p. 75-82.

Dai, P., Chen, H., Yang, B., Wang, H., Yang, Q., Zhang, H., Chen, W., Chen, Y. Q. 2016. Mortierella alpina feed supplementation enriched hen eggs with DHA and AA. RSC advances, vol. $6, \quad$ no. 3, p. 1694-1699. https://doi.org/10.1039/C5RA22417A

Dvořák, P., Doležalová, J., Suchý, P. 2009. Photocolourimetric determination of yolk colour in relation to selected quality parameters of eggs. Journal of the Science of Food and Agriculture, vol. 89, no. 11, p. 1886-1889. https://doi.org/10.1002/jsfa.3668

Dvořák, P., Straková, E., Kunová, J., Kunová, V. 2007. Egg yolk colour upon the composition of the feeding mixture for laying hens. Acta Veterinaria Brno, vol. 76, p. 121-127. https://doi.org/10.2754/avb200776010121

Eun, J. S., Beauchemin, K. A., Hong, S. H., Bauer, M. W. 2006. Exogenous enzymes added to untreated or ammoniated rice straw: effects on in vitro fermentation characteristics and degradability. Animal Feed Science and Technology, vol. 131, p. 87-102. https://doi.org/10.1016/j.anifeedsci.2006.01.026

European Parliament and Council, 2010. Directive 2010/63/EU of The European Parliament and of The Council of 22 September 2010 on the protection of animals used for scientific purposes. OJ L 276, 20.10.2010, p. 33-79.

Faitarone, A. B. G., Garcia, E. A., Roca, R. O., Andrade, E. N., Vercese, F., Pelícia, K. 2016. Yolk colour and lipid oxidation of the eggs of commercial white layers fed diets supplemented with vegetable oils. Brazilian Journal of Poultry Science, vol. 18, no. 1, p. 9-16. https://doi.org/10.1590/1516-635X1801009-016

Fennema, O. R. 2000. Química de los alimentos. $22^{\text {nd }}$ ed. ZARAGOZA, SPAIN: Editorial Acribia, 1280 p. ISBN 97884-200-0914-8.

Ghadiri, M., Mamlouk, M., Spicer, P., Jarolimek, W., Grau, G. E., Young, P. M., Traini, D. 2016. Effect of polyunsaturated fatty acids (PUFAs) on airway epithelial cells' tight junction. Pulmonary Pharmacology \& Therapeutics, vol. $40, \quad$ p. 30-38. https://doi.org/10.1016/j.pupt.2016.07.004

Giampietro, A., Scatolini, A. M., Boiago, M. M., Coró, D. M. O., Souza, H., B. A., Souza, P. A., Lima, T. M. A., Pizzolante, C. C. 2008. TBARS methodology study in eggs (in Spain). Available at: http://www.avisite.com.br/cet/img/20080506_alinetbars.pdf.

Gładkowski, W., Kiełbowicz, G., Chojnacka, A., Gil, M., Trziszka, T., Dobrzański, Z., Wawrzeńczyk, C. 2011. Fatty acid composition of egg yolk phospholipid fractions following feed supplementation of Lohmann Brown hens with humic-fat praparations. Food Chemistry, vol. 126, p. 10131018. https://doi.org/10.1016/j.foodchem.2010.11.112

Graminha, E. B. N. , Gonçalves, A. Z. L., Pirota, R. D. P. B., Balsalobre, M. A. A., Da Silva, R., Gomes E. 2008. Enzyme production by solid-state fermentation: Application to animal nutrition. Animal Feed Science and Technology, vol. $144, \quad$ p. $1-22$. https://doi.org/10.1016/j.anifeedsci.2007.09.029

Hamelin, C., Hernandez, J. M. 2011. Colour of table eggs and egg products: comparison of three available methods. In Actes des 9èmes Journées de la Recherche Avicole, Tours, France, 29 et 30 mars 2011, p. 676-680. https://doi.org/10.1590/S1516-35982010001200021

Cherian, G., Traber, M. G., Goeger, M. P., Leonard, S. W. 2007. Conjugated linoleic acid and fish oil in laying hen diets: effects on egg fatty acids, thiobarbituric acid reactive substances, and tocoferols during storage. Poultry Science, vol. 86, no. 5, p. 953-958. https://doi.org/10.1093/ps/86.5.953

Ketta, M., Tůmová, E. 2016. Eggshell structure, measurements, and quality-affecting factors in laying hens: a review. Czech Journal of Animal Science, vol. 61, no. 7, p. 299-309. https://doi.org/10.17221/46/2015-CJAS

Klempová, T., Basil, E., Kubatová, A., Čertik, M. 2013. Biosynthesis of gamma-linolenic acid and beta-carotene by Zygomycetes fungi. Biotechnology Journal, vol. 8, no. 7, p. 794-800. https://doi.org/10.1002/biot.201200099 
Kopřiva, V., Suchý, P., Straková, E., Žd’árský, M., Dvořák, P. 2014. Colour and viscosity of egg yolk after addition of beetroot to feed for laying hens. Acta Veterinaria Brno, vol. 83, p. 39-44. https://doi.org/10.2754/avb201483010039

Koreleski, J., Świątkiewicz, S., Iwanowska, A. 2003. Lipid fatty acids composition and oxidative susceptibility in eggs of hens fed a fish diet supplemented with vitamin E, C, or synthetic antioxidant. Journal of Animal and Feed Sciences, vol. 12, p. 561-572. https://doi.org/10.22358/jafs/67731/2003

Kozelová, D., Országhová, D., Matejková, E., Fikselová, M., Horská, E., Durdíková, D., Matysik-Pejas, R. 2018. Eggs and their consumption affected by the different Factors of purchase. Potravinarstvo Slovak Journal of Food Sciences, vol. 12, no. 1, p. 570-577. https://doi.org/10.5219/944

Kusum, M., Verma, R. C., Renu, M., Jain, H. K., Deepak S. 2018. A review: Chemical composition and utilization of egg. International Journal of Chemical Studies, vol. 6, p. 31863189.

Laganá, C., Pizzolante, C. C., Saldanha, E. S. P. B., Moraes J. E. 2011. Turmeric root and annatto seed in second-cycle layer diets: performance and egg quality. Brasilian Journal of Poultry Science, vol. 13 , no. 3, p. 172-176. https://doi.org/10.1590/S1516-635X2011000300002

Lei, K., Li, Y. L., Yu, D. Y., Rajput, I. R., Li, W. F. 2013. Influence of dietary inclusion of Bacillus licheniformis on laying performance, egg quality, antioxidant enzyme activities, and intestinal barrier function of laying hens. Poultry Science, vol. 92, p. 2389-2395. https://doi.org/10.3382/ps.2012-02686

Lokaewmanee, K., Mompanuon, S., Khumpeerawat, P., Yamauchi, K. E. 2009. Effects of dietary mulberry leaves (Morus alba L.) on egg yolk colour. The Journal of Poultry Science, vol 46, no. 2, p. 112-115. https://doi.org/10.2141/jpsa.46.112

Lokaewmanee, K., Yamauchi, K. E., Komori, T., Saito, K. 2010. Effects on egg yolk colour of paprika or paprika combined with marigold flower extracts. Italian Journal of Animal Science, vol. 9, p. 356-359. https://doi.org/10.4081/ijas.2010.e67

Marcinčák, S., Klempová, T., Bartkovský, M., Marcinčáková, D., Zdolec, N., Popelka, P., Mačanga, J., Čertík, M. 2018. Effect of fungal solid-state fermented product in broiler chicken nutrition on quality and safety of produced breast meat. BioMed Research International, vol. 2018. p. 1-8. https://doi.org/10.1155/2018/2609548

Nagy, J., Jevinová, P., Korenéková, B., Kožárová, I., Pipová, M., Popelka, P., Turek, P. 2011. Production technology and quality of poultry, fish, game and honey products (in Slovak) 1st ed. Košice, Slovakia: Publishing Center of the University of Veterinary Medicine.

Neijat, M., Ojekudo, O., House, J. D. 2016. Effect of flaxseed oil and microalgae DHA on the production performance, fatty acids ant total lipids of egg yolk and plasma in laying hens. Prostaglandins, leukotrienes and Essential Fatty Acids, vol. 2115, p. 77-88. https://doi.org/10.1016/j.plefa.2016.10.010

Pandey, A. 2003. Solid-state fermentations. Biochemical Engineering Journal, vol. 13, p. 81-84. https://doi.org/10.1016/S1369-703X(02)00121-3

Nimalaratne, C., Wu, J. 2015. Hen Egg as an Antioxidant Food Commodity: A Review. Nutrients, vol. 7, p. 8274-8293. https://doi.org/10.3390/nu7105394

Reitznerová, A., Šuleková, M., Nagy, J., Marcinčák, S., Semjon, B., Čertík, M., Klempová, T. 2017. Lipid peroxidation process in meat and meat products: a comparison study of malondialdehyde determination between modified 2-Thiobarbit.uric acid spectrophotometric method and reverse-phase high-performance liquid chromatography. Molecules, vol. 22, no. 11, p. 1988. https://doi.org/10.3390/molecules22111988

Ren, Y., Wu, J., Renema, R. 2010. Nutritional and Health Attributes of Eggs. In Guerrero-Legarreta, I. et al. Handbook of Poultry Science and Technology, Primary Processing. New Jersey: John Wiley and Sons, Inc., p. 535-579. ISBN 9780470185520.

Réhault-Godbert, S., Guyot, N., Nys, Y. 2019. The Golden Egg: Nutritional Value, Bioactivities, and Emerging Benefits for Human Health. Nutrients, vol. 11, p. 1-26. https://doi.org/10.3390/nu11030684

Saeid, A., Chojnacka, K. 2015. Toward production of microalgae in photobioreactors under temperate climate. Chemical Engineering Research and Design, vol. 93, p. 377391.https://doi.org/10.1016/j.cherd.2014.06.008

Saeid, A., Chojnacka, K., Opaliński, S., Korczyński, M. 2016. Biomass of Spirulina maxima enriched by biosorption process as a new feed supplement for laying hens. Algal $\begin{array}{llll}\text { research, } & \text { vol. } & 19, & \text { p. }\end{array}$ https://doi.org/10.1016/j.algal.2016.02.008

Schreiner, M., Hulan, H. W., Razzazi-fazel, E., Böhm, J., Iben, C. 2004. Feeding laying hens seal blubber oil: effects on egg yolk incorporation, stereospecific distribution of omega-3 fatty acids, and sensory aspects. Poultry Science, vol. 83, p. 462-473. https://doi.org/10.1093/ps/83.3.462

Silva, J. H. V., Albino, L. F. T., Godoi, M. J. S. 2000. Efeito do extrato de urucum na pigmentaçäo de gema dos ovos. Revista Brasileira de Zootecnia, vol. 29, no. 5, p. 1435-1439. https://doi.org/10.1590/S1516-35982000000500022

Spasewski, N. J., Dragojlović, D. M., Čolovič, D. S., Vidosavljević, S. Ž., Peulić, T., Rakita, S. M., Kokić, B. M. 2018. Influence of dietary carrot and paprika on egg physical characteristics and yolk colour. Food and Feed Research, vol. 45, no. 1, p. 59-66. https://doi.org/10.5937/FFR1801059S

Spasewski, N. J., Tasić, T., Vukmirović, D., Banjac, V., Rakita, S., Lević, J., Duragić, O. 2017. Effect of different levels of marigold and paprika on egg production and yolk colour. Archiva Zootechnica, vol. 20, no. 2, p. 51-57.

Sugiharto S., Ranjitkar, S. 2019. Recent advances in fermented feeds towards improved broiler chicken performance, gastrointestinal tract microecology and immune responses: A review. Animal Nutrition, vol. 5, p. 1-10. https://doi.org/10.1016/j.aninu.2018.11.001

Sugino, H., Nitoda, T., Juneja, L. R. 1997. General chemical composition of hen eggs. In Yamamoto T. et al. Hen Eggs: Basic and Applied Science. Boca Raton, FL : CRC Press. p. 13-24. ISBN 9780849340055.

Tůmová, E., Ebeid, T. 2005. Effect of time of oviposition on egg quality characteristics in cages and in litter housing system. Czech Journal of Animal Sciences, vol. 50, p. 129134. https://doi.org/10.17221/4006-CJAS

Wang, J., Yue, H., Wu, S., Zhang, H., Qi, G. 2017. Nutritional modulation of health, egg quality and environmental pollution of the layers. Animal Nutrition, vol. 3, no. 2, p. 91-96. https://doi.org/10.1016/j.aninu.2017.03.001

Yang, S., Zhang, H. 2016. Enhanced polyunsaturated fatty acids production in Mortierella alpina by SSF and the enrichment in chicken breasts. Food \& Nutrition Research, vol. 60, p. 1-8. https://doi.org/10.3402/fnr.v60.30842

\section{Acknowledgments:}

This work was supported by the Slovak Research and Development Agency under the contracts No. APVV-18-0039 and APVV-14-0397. Thanks to Salonee Udani, a native 
speaker from London, a student at the University of Veterinary Medicine and Pharmacy in Košice (Slovakia), for English proofreading.

\section{Contact address:}

*Boris Semjon, University of Veterinary Medicine and Pharmacy in Košice, Department of Food Hygiene and Technology, Komenského 73, 04181 Košice, Slovakia, Tel.: +421917315905,

E-mail: boris.semjon@uvlf.sk

ORCID: https://orcid.org/0000-0003-4941-3394

Eva Dudriková, University of Veterinary Medicine and Pharmacy in Košice, Department of Food Hygiene and Technology, Komenského 73, 04181 Košice, Slovakia, Tel.: $+421915984582$

E-mail: eva.dudrikova@uvlf.sk

ORCID: https://orcid.org/0000-0001-6814-1756

Iveta Jad'uttová, University of Veterinary Medicine and Pharmacy in Košice, Department of Food Hygiene and Technology, Komenského 73, 04181 Košice, Slovakia, Tel.: +421915984756,

E-mail: iveta.jaduttova@student.uvlf.sk

ORCID: https://orcid.org/0000-0001-6766-0685

Martin Bartkovský, University of Veterinary Medicine and Pharmacy in Košice, Department of Food Hygiene and Technology, Komenského 73, 04181 Košice, Slovakia, Tel.: +421917315905

E-mail: martin.bartkovsky@uvlf.sk

ORCID: https://orcid.org/0000-0002-9205-4289
Tatiana Klempová, Slovak University of Technology, Institute of Biotechnology, Faculty of Chemical and Food Technology, Radlinského 9, 81237 Bratislava, Slovakia, Tel.: +421259325565,

E-mail: tatiana.klempova@stuba.sk

ORCID: https://orcid.org/0000-0002-6341-1742

Dana Marcinčáková, University of Veterinary Medicine and Pharmacy in Košice, Department of Pharmacology and Toxicology, Komenského 73, 04181 Košice, Slovakia, Tel.: +421917355747,

E-mail: dana.marcincakova@uvlf.sk

ORCID: https://orcid.org/0000-0002-5956-915X

Ondrej Slaný, Slovak University of Technology, Institute of Biotechnology, Faculty of Chemical and Food Technology, Radlinského 9, 81237 Bratislava, Slovakia, Tel.: +421259325565,

E-mail: ondrej.slany@ stuba.sk

ORCID: https://orcid.org/0000-0002-6341-1742

Slavomír Marcinčák, University of Veterinary Medicine and Pharmacy in Košice, Department of Food Hygiene and Technology, Komenského 73, 04181 Košice, Slovakia, Tel.: +421915984756,

E-mail: slavomir.marcincak@uvlf.sk

ORCID: https://orcid.org/0000-0002-1659-2552

Corresponding author: * 